\title{
Learning styles preferences among graduate and undergraduate pharmacy students in Pakistan: Does it matter?
}

\author{
Madeeha Malik iD, Mahjabeen Ahmad, Azhar Hussain \\ Hamdard Institute of Pharmaceutical Sciences, Hamdard University Islamabad, Pakistan
}

\section{Keywords \\ Graduate pharmacy student \\ Pakistan \\ Undergraduate pharmacy student \\ VARK questionnaire}

Correspondence
Madeeha Malik
Director
Hamdard Institute of
Pharmaceutical Sciences
Hamdard University
Islamabad
Pakistan
madeehamalik15@gmail.com

\section{Abstract}

Introduction: The quality of student learning depends on the approaches that are used for learning. An association exists between different learning methodologies and learning outcomes. Objective: The present study was designed to assess preferences for different learning styles among pharmacy students in Islamabad, Pakistan. Method: A descriptive cross-sectional study design was used. A selfadministered pre-validated questionnaire VARK version 8.0 was distributed to 387 undergraduate students from both public and private pharmacy schools located in Islamabad and 100 graduate students selected from public sector pharmacy schools using the convenience sampling technique. After data collection, it was cleaned, coded, and analysed using SPSS version 21. Results: The results of the present study showed that the most common learning style among graduate students was Aural (Total Score $=492)$, followed by kinesthetic (Total Score $=467)$, read/write (Total Score $=351)$, and visual (Total Score $=290$ ). On the other hand, the most common learning style among undergraduate students was Aural (Total score $=1926$ ), followed by kinesthetic (Total score $=1859$ ), read/write (Total score $=1241)$, and visual (Total score $=1166)$. Conclusion: The result of the present study concluded aural as the most preferred learning style followed by kinesthetic among both undergraduate and graduate pharmacy students. Graduate female pharmacy students showed more preference towards kinesthetic learning style as compared to graduate male students who showed more preference towards aural learning modality. However, both undergraduate and graduate male and female students preferred aural learning style. Identifying the learning style at the start of pharmacy degree can help mentors to assess the appropriate field for them after graduation. Moreover, information regarding such styles would be helpful for stakeholders to devise effective strategies for teaching and introduce changes accordingly into the curriculum.
\end{abstract}

\section{Introduction}

Learning style is a characteristic cognitive, affective, and psychosocial behaviour that serves as a relatively stable indicator of a learner's perception, interaction, and response to the learning environment (Robles, Cox, \& Seifert, 2012). Innovative learning skills and approaches are beneficial at all educational levels, and focusing on them makes the learning process more effective. Various learning style models and theories have gained attention during the last two decades throughout the world. Every student has a diverse way of learning, and a single teaching method might not be effective for every student (Radwan, 2014). Students enrolled in medical degree programs are supposed to be "lifelong learners", and their learning quality and success in studies depend on their approach as well as learning style. The opportunities for achieving the desired learning outcomes can be accomplished by reducing the gap between interpretation by learning and teaching methodology (Ahmady et al., 2019). Medical students being from diverse educational backgrounds imparts a significant burden on the faculty members for introducing innovative teaching modules by incorporating different learning styles of students along with innovative teaching strategies for motivating them to improve their performance. The curriculum related to medical education is difficult for students as well as faculty members as immense information needs to be taught and learned in a limited time frame (Ahil et al., 
2016). Therefore, newly introduced teaching methodologies are only successful when implemented according to the preferences of students for learning (Adams, Bell, \& Griffin, 2007).

The different learning styles are classified on the basis of the preferences of individuals. If the learners prefer a single style, then they are said to be unimodal, but if two or more styles are preferred, then they are known as multimodal (Samarakoon et al., 2013). The academic success of students depends on their choice of learning styles. Identifying the learning style can help the students to improve their academic performance (Breckler, Joun, \& Ngo, 2009). Low GPA of students using a single mode of learning was reported in Saudi Arabia. Moreover, aural learning style followed by kinesthetic style of learning was the most commonly preferred learning style among students in Saudi Arabia (Al-Saud, 2013). Another study conducted in the United Arab Emirates (UAE) showed that multimodal style was common among both preclinical and clinical students. The unimodal style was used by only a few students. Both preclinical and clinical students preferred kinesthetic mode for the unimodal learning style (Khalil, Ahmed, \& Gawish, 2014).

The quality of student learning depends on the approaches that are used for learning. An association exists between different learning methodologies and learning outcomes. It was reported that conceptual approaches towards learning lead to a better quality of learning outcomes, while surface approaches resulted in poor quality of learning outcomes in Pakistan (Qureshi \& Ullah, 2014). Another study conducted in Pakistan related to learning and instructional strategies reported that alignment of learning preferences of all students with the teacher's instructional strategies could enhance learning as well as the academic performance of the students (Bhalli, Khan, \& Sattar, 2016). Cultural and gender differences are important factors affecting learning styles. Innovation in teaching approaches had successfully resolved the contributing barriers towards learning. Awareness regarding culture and gender sensitivity in teaching and practice needs to be promoted in Pakistan (Fooladi, 2008).

Pharmacy education is at a transitional stage in terms of the curriculum in Pakistan. The main challenge faced by the education sector after upgrading B.Pharmacy to a Pharm.D degree is the unavailability of experienced and qualified faculty. Moreover, the major challenge for the graduating pharmacist and a possible reason for the lack of acceptance by the medical and para-medical staff could be attributed to the lack of involvement of the pharmacist as a member of the healthcare team and in direct patient care in Pakistan (Khan, 2011). The profile for styles of learning has not been identified for pharmacy students in developing countries, including
Pakistan. The development of this profile can aid in identifying the preferred learning styles of students enrolling in the pharmacy profession. Thus, the present study was designed to assess preferences for different learning styles among pharmacy students in Islamabad, Pakistan.

\section{Methods}

A descriptive cross-sectional study design was used to assess the learning styles preferred by pharmacy students in Pakistan. Study approval was taken from the Ethical Committee of Hamdard University (BASR-819.21). Study respondents were students of both undergraduate and graduate levels. Undergraduate students from both public and private pharmacy schools were included while graduate from only public sector pharmacy schools was included as respondents.

Approval was also taken from Directors and Head of Departments of various pharmacy schools. Respondents were briefed regarding the nature and objectives of the study, and verbal and written consents were obtained prior to data collection. Respondents were assured of the confidentiality of their responses and their right to withdraw from the study at any time. The sample size was calculated by using Rao soft at a $95 \%$ confidence interval and a $5 \%$ margin of error. The sample size for undergraduate students was 387 and for graduate students was 100 . Convenience sampling technique was used, and all the respondents available at the time of data collection and willing to participate were included. A self-administered pre-validated questionnaire VARK version 8.0 was used. It consists of 16 questions with four options of each learning style, i.e. visual (V), aural (A), $\mathrm{read} /$ write $(\mathrm{R}), \geq$ and kinesthetic $(K)$. The respondents can also select more than one option to define their style of learning. Pilot testing was conducted on $10 \%$ of the sample. The Cronbach's alpha value was found to be 0.80 for VARK. After data collection, it was cleaned, coded, and analysed using SPSS version 21.

\section{Results \\ Demographic characteristics of respondents}

Out of 100 graduate students, $31 \%(n=31)$ were males while $69 \%$ ( $n=69$ ) were females. Out of the total graduates' respondents, $60.2 \%(n=62)$ had only done Pharm.D and $36.9 \%(n=38)$ were Master (M.Phil). Hundred percent $(n=100)$ of graduates were from the public sector. On the other hand, out of 387 undergraduate students, $34.6 \%(n=134)$ were males while $65.4 \%(n=253)$ were females. Sixty five percent $(n=255)$ of them were from the private sector while $34 \%$ 
percent $(n=132)$ were from public sector. Of the total undergraduate students, $42.1 \%(n=163)$ students were studying in first professional year, $12.4 \%(n=48)$ in second professional year, $18.1 \%(n=70)$ in third professional year, $14.5 \%(n=56)$ in fourth professional year and $12.9 \%(n=50)$ were from final professional year. A detailed description is given in Table $\mathrm{I}$.

Table I: Demographic characteristics of pharmacy students

\begin{tabular}{|c|c|c|}
\hline Indicator & $\begin{array}{c}\text { n (\%) } \\
\text { Graduate } \\
\text { students }\end{array}$ & $\begin{array}{c}\text { n (\%) } \\
\text { Undergraduate } \\
\text { students }\end{array}$ \\
\hline \multicolumn{3}{|l|}{ Gender } \\
\hline Male & $31(31 \%)$ & $253(65.4 \%)$ \\
\hline Female & 69 (69\%) & $134(34.6 \%)$ \\
\hline \multicolumn{3}{|l|}{ Province } \\
\hline Punjab & 73 (70.9\%) & $183(47.3 \%)$ \\
\hline KPK & $8(7.8 \%)$ & $38(7.8 \%)$ \\
\hline Federal & 19 (18.4\%) & 45 (11.6 \%) \\
\hline A.J. $K$ & $\mathrm{Nil}$ & 129 (33.3 \%) \\
\hline \multicolumn{3}{|l|}{ Institute } \\
\hline Private & 100 & 255 (65.9\%) \\
\hline \multirow[t]{2}{*}{ Public } & $(100 \%)$ & $132(34.1 \%)$ \\
\hline & 0 & \\
\hline \multicolumn{3}{|l|}{ Level of Education } \\
\hline Bachelor & 62 (60.2\%) & $387(99.9 \%)$ \\
\hline Masters & 38 (36.9\%) & - \\
\hline \multicolumn{3}{|l|}{$\begin{array}{l}\text { Professional } \\
\text { (undergraduates) }\end{array}$} \\
\hline $1^{\text {st }}$ & & $48(12.4 \%)$ \\
\hline $2^{\text {nd }}$ & & 70 (18.1\%) \\
\hline $3^{\text {rd }}$ & & $56(14.5 \%)$ \\
\hline $4^{\text {th }}$ & & $50(12.9 \%)$ \\
\hline \multicolumn{3}{|l|}{$5^{\text {th }}$} \\
\hline \multicolumn{3}{|l|}{ Setting } \\
\hline Urban & 100 & 327 (84.5\%) \\
\hline \multirow[t]{2}{*}{ Rural } & $(100 \%)$ & $60(15.5 \%)$ \\
\hline & 0 & \\
\hline
\end{tabular}

\section{Preferences of learning styles among graduate pharmacy students}

The results of the present study showed that the most common learning style among graduate students was Aural (Total Score $=492$ ), followed by kinesthetic (Total Score $=467)$, read $/$ write (Total Score $=351)$, and visual (Total Score $=290)$. A detailed description is given (Table II).

\section{Preferences of learning styles among undergraduate pharmacy students}

The results of the study showed that the most common learning style among undergraduate students was Aural (Total score $=1926$ ), followed by kinesthetic (Total score $=1859)$, read $/$ write $($ Total score $=1241)$, and visual (Total score $=1166)$. A detailed description is given in Table III.

\section{Preferences of learning styles among different genders of graduate pharmacy students}

The results highlighted that male graduate students had a very strong preference for aural learning style $(A=158)$, followed by kinesthetic style ( $K=125)$, read/write $(R=119)$, and visual $(V=94)$, while females had a strong preference towards kinesthetic learning style $(K=342)$ followed by aural $(A=334)$, read/ write $(R=232)$ and visual $(V=196)$. A detailed description is given in Table IV.

Preferences of learning styles among different genders of undergraduate pharmacy students

The results highlighted that male undergraduate students had a very strong preference for aural learning style $(A=672)$ followed by kinesthetic $(K=621)$, read/write $(R=462)$, vision $(V=389)$, while female undergraduate students also had a strong preference towards aural learning style $(A=1254)$, followed by kinesthetic $(K=1238)$, read /write $(R=779)$, visual $(\mathrm{V}=777)$. A detailed description is given in Table $\mathrm{V}$.

\section{Discussion}

Every individual is unique in the way of understanding and comprehending information and knowledge; therefore, exposure to different teaching and learning methods can enhance his/her learning preferences. Every individual has a certain degree of preference for each type of study skill, and a majority of them have dominance in one or more styles of learning (Khanal et al., 2019). The results of the present study revealed that the overall preferred sensory learning modality by both undergraduates and graduates' pharmacy students was unimodal. The most preferred learning style was aural followed by kinesthetic learning style. This might be due to the fact that students may believe in their I.Q and not show interest in making too much effort to do some more initiative and quality work. Similar results were reported from a study conducted in Saudi Arabia, where aural was found to be the most preferred learning style (Rezigalla \& Ahmed, 2019). 
Table II: Preferences of learning styles among graduate pharmacy students

\begin{tabular}{|c|c|c|c|c|c|c|c|c|}
\hline \multirow[t]{2}{*}{ Indicator } & \multicolumn{2}{|c|}{ Visual (V) } & \multicolumn{2}{|c|}{ Aural (A) } & \multicolumn{2}{|c|}{ Read/write (R) } & \multicolumn{2}{|c|}{ Kinesthetic (K) } \\
\hline & $\mathbf{n}$ & $(\%)$ & $\mathbf{n}$ & (\%) & $\mathbf{n}$ & (\%) & $\mathbf{n}$ & (\%) \\
\hline $\begin{array}{l}\text { I need to find the way to a shop that a friend has } \\
\text { recommended. I would; }\end{array}$ & 30 & 30 & 34 & 34 & 26 & 26 & 10 & 10 \\
\hline $\begin{array}{l}\text { A website has a video showing how to make a special graph } \\
\text { or chart. There is a person speaking, some lists and words } \\
\text { describing what to do and some diagrams. I would learn } \\
\text { most from; }\end{array}$ & 27 & 27 & 30 & 30 & 13 & 13 & 30 & 30 \\
\hline I want to find out more about a tour that I am going on. & 29 & 29 & 34 & 34 & 16 & 16 & 21 & 21 \\
\hline $\begin{array}{l}\text { When choosing a career or an area of study, these are } \\
\text { important for me: }\end{array}$ & 7 & 7 & 40 & 40 & 15 & 15 & 38 & 38 \\
\hline When I am learning I; & 9 & 9 & 21 & 21 & 30 & 30 & 40 & 40 \\
\hline $\begin{array}{l}\text { I want to save more money and to decide between a range } \\
\text { of options, I would; }\end{array}$ & 11 & 11 & 36 & 36 & 15 & 15 & 38 & 38 \\
\hline $\begin{array}{l}\text { I want to learn how to play a new board game or card } \\
\text { game. I would: }\end{array}$ & 16 & 16 & 37 & 37 & 30 & 30 & 17 & 17 \\
\hline I have a problem with my heart. I would prefer that doctor: & 33 & 33 & 27 & 27 & 20 & 20 & 20 & 20 \\
\hline $\begin{array}{l}\text { I want to learn to do something new on a computer. I } \\
\text { would: }\end{array}$ & 14 & 14 & 31 & 31 & 18 & 18 & 37 & 37 \\
\hline When learning from the internet. I like: & 7 & 7 & 9 & 9 & 36 & 36 & 48 & 48 \\
\hline I want to learn about a new project. I would ask for: & 25 & 25 & 22 & 22 & 18 & 18 & 35 & 35 \\
\hline I want to learn how to take better photos. I would: & 13 & 13 & 36 & 36 & 23 & 23 & 28 & 28 \\
\hline I prefer a presenter or a teacher who uses: & 17 & 17 & 33 & 33 & 21 & 21 & 29 & 29 \\
\hline $\begin{array}{l}\text { I have finished a competition or test and I would like some } \\
\text { feedback. I would like to have feedback: }\end{array}$ & 10 & 10 & 39 & 39 & 22 & 22 & 29 & 29 \\
\hline $\begin{array}{l}\text { I want to find out about a house or an apartment. Before } \\
\text { visiting it I would want: }\end{array}$ & 24 & 24 & 39 & 39 & 20 & 20 & 17 & 17 \\
\hline $\begin{array}{l}\text { I want to assemble a wooden table that came in parts } \\
\text { (kitset). I would learn best from: }\end{array}$ & 18 & 18 & 24 & 24 & 28 & 28 & 30 & 30 \\
\hline Total Score & 290 & & 492 & & 351 & & 467 & \\
\hline
\end{tabular}

Table III: Preferences of learning styles among undergraduate pharmacy students

\begin{tabular}{|c|c|c|c|c|c|c|c|c|}
\hline \multirow[t]{2}{*}{ Indicator } & \multicolumn{2}{|c|}{ Visual (V) } & \multicolumn{2}{|c|}{ Aural (A) } & \multicolumn{2}{|c|}{ Read/write (R) } & \multicolumn{2}{|c|}{ Kinesthetic (K) } \\
\hline & $\mathbf{n}$ & $(\%)$ & $\mathbf{n}$ & (\%) & $\mathbf{n}$ & $(\%)$ & $\mathbf{n}$ & $(\%)$ \\
\hline $\begin{array}{l}\text { I need to find the way to a shop that a friend has } \\
\text { recommended. I would; }\end{array}$ & 105 & 27.1 & 168 & 43.4 & 53 & 13.7 & 61 & 15.8 \\
\hline $\begin{array}{l}\text { A website has a video showing how to make a special graph } \\
\text { or chart. There is a person speaking, some lists and words } \\
\text { describing what to do and some diagrams. I would learn } \\
\text { most from; }\end{array}$ & 125 & 32.3 & 90 & 23.3 & 59 & 15.2 & 113 & 29.2 \\
\hline I want to find out more about a tour that I am going on. & 92 & 23.8 & 143 & 37 & 54 & 14 & 98 & 25.3 \\
\hline $\begin{array}{l}\text { When choosing a career or an area of study, these are } \\
\text { important for me: }\end{array}$ & 51 & 13.2 & 162 & 41.9 & 41 & 10.6 & 133 & 34.4 \\
\hline When I am learning I; & 56 & 14.5 & 78 & 20.2 & 100 & 25.8 & 153 & 39.5 \\
\hline $\begin{array}{l}\text { I want to save more money and to decide between a range } \\
\text { of options, I would; }\end{array}$ & 50 & 12.9 & 130 & 33.6 & 68 & 17.6 & 139 & 35.9 \\
\hline $\begin{array}{l}\text { I want to learn how to play a new board game or card game. } \\
\text { I would: }\end{array}$ & 72 & 18.6 & 115 & 29.7 & 109 & 28.2 & 91 & 23.5 \\
\hline I have a problem with my heart. I would prefer that doctor: & 107 & 27.6 & 130 & 33.6 & 63 & 16.3 & 87 & 22.5 \\
\hline $\begin{array}{l}\text { I want to learn to do something new on a computer. I } \\
\text { would: }\end{array}$ & 45 & 11.6 & 119 & 30.7 & 81 & 20.9 & 142 & 36.7 \\
\hline When learning from the internet. I like: & 54 & 14 & 34 & 8.8 & 95 & 24.5 & 204 & 52.7 \\
\hline I want to learn about a new project. I would ask for: & 91 & 23.5 & 101 & 26.1 & 87 & 22.5 & 108 & 27.9 \\
\hline I want to learn how to take better photos. I would: & 54 & 14 & 134 & 34.6 & 77 & 19.9 & 122 & 31.5 \\
\hline I prefer a presenter or a teacher who uses: & 60 & 15.5 & 142 & 36.7 & 68 & 17.6 & 117 & 30.2 \\
\hline $\begin{array}{l}\text { I have finished a competition or test and I would like some } \\
\text { feedback. I would like to have feedback: }\end{array}$ & 38 & 9.8 & 123 & 31.8 & 120 & 31 & 106 & 27.4 \\
\hline $\begin{array}{l}\text { I want to find out about a house or an apartment. Before } \\
\text { visiting it I would want: }\end{array}$ & 89 & 23 & 154 & 39.8 & 74 & 19.1 & 70 & 18.1 \\
\hline $\begin{array}{l}\text { I want to assemble a wooden table that came in parts } \\
\text { (kitset). I would learn best from: }\end{array}$ & 77 & 19.9 & 103 & 26.6 & 92 & 23.8 & 115 & 29.7 \\
\hline Total score & 1166 & & 1926 & & 1241 & & 1859 & \\
\hline
\end{tabular}


Table IV: Preferences of learning styles among different gender of graduate pharmacy students

\begin{tabular}{|c|c|c|c|c|c|c|c|c|}
\hline \multirow[t]{2}{*}{ Indicator } & \multicolumn{2}{|c|}{$\mathbf{V}$} & \multicolumn{2}{|c|}{ A } & \multicolumn{2}{|c|}{$\mathbf{R}$} & \multicolumn{2}{|c|}{$\mathbf{K}$} \\
\hline & $\mathbf{M}$ & $\mathbf{F}$ & $\mathbf{M}$ & $\mathbf{F}$ & $\mathbf{M}$ & $\mathbf{F}$ & M & $\mathbf{F}$ \\
\hline $\begin{array}{l}\text { I need to find the way to a shop that a friend has } \\
\text { recommended. I would most learn from. }\end{array}$ & 8 & 22 & 12 & 22 & 10 & 16 & 1 & 9 \\
\hline $\begin{array}{l}\text { A website has a video showing how to make a } \\
\text { special graph or chart. There is a person speaking, } \\
\text { some lists and words describing what to do and } \\
\text { some diagrams. I would learn most from; }\end{array}$ & 5 & 22 & 10 & 20 & 5 & 8 & 11 & 19 \\
\hline $\begin{array}{l}\text { I want to find out more about a turn that I am going } \\
\text { on. }\end{array}$ & 9 & 20 & 10 & 24 & 7 & 9 & 5 & 16 \\
\hline $\begin{array}{l}\text { When choosing a career or an area of study, these } \\
\text { are important for me: }\end{array}$ & 2 & 5 & 14 & 26 & 5 & 10 & 10 & 28 \\
\hline When I am learning I; & 4 & 5 & 9 & 12 & 10 & 20 & 8 & 32 \\
\hline $\begin{array}{l}\text { I want to save more money and to decide between } \\
\text { a range of options, I would }\end{array}$ & 4 & 7 & 12 & 24 & 6 & 9 & 9 & 29 \\
\hline $\begin{array}{l}\text { I want to learn how to play a new board game or } \\
\text { card game. I would: }\end{array}$ & 4 & 12 & 14 & 23 & 8 & 22 & 5 & 12 \\
\hline $\begin{array}{l}\text { I have a problem with my heart. I would prefer that } \\
\text { doctor: }\end{array}$ & 14 & 19 & 4 & 23 & 8 & 12 & 5 & 15 \\
\hline $\begin{array}{l}\text { I want to learn to do something new on a } \\
\text { computer. I would: }\end{array}$ & 5 & 9 & 11 & 20 & 5 & 13 & 10 & 27 \\
\hline When learning from the internet. I like: & 3 & 4 & 4 & 5 & 12 & 24 & 12 & 36 \\
\hline I want to learn about a new project. I would ask for: & 7 & 18 & 5 & 17 & 7 & 11 & 12 & 23 \\
\hline I want to learn how to take better photos. I would: & 5 & 8 & 9 & 27 & 9 & 14 & 8 & 20 \\
\hline I prefer a presenter or a teacher who uses: & 8 & 9 & 10 & 23 & 7 & 14 & 6 & 23 \\
\hline $\begin{array}{l}\text { I have finished a competition or test and I would } \\
\text { like some feedback. I would like to have feedback: }\end{array}$ & 4 & 6 & 12 & 27 & 7 & 15 & 8 & 21 \\
\hline $\begin{array}{l}\text { I want to find out about a house or an apartment. } \\
\text { Before visiting it I would want: }\end{array}$ & 7 & 17 & 12 & 27 & 7 & 13 & 5 & 12 \\
\hline $\begin{array}{l}\text { I want to assemble a wooden table that came in } \\
\text { parts (kitset). I would learn best from: }\end{array}$ & 5 & 13 & 10 & 14 & 6 & 22 & 10 & 20 \\
\hline Total score & 94 & 196 & 158 & 334 & 119 & 232 & 125 & 342 \\
\hline
\end{tabular}

Table V: Preferences of learning styles among different gender of undergraduate students

\begin{tabular}{|c|c|c|c|c|c|c|c|c|}
\hline \multirow[t]{2}{*}{ Indicator } & \multicolumn{2}{|c|}{$\mathbf{V}$} & \multicolumn{2}{|c|}{ A } & \multicolumn{2}{|c|}{$\mathbf{R}$} & \multicolumn{2}{|c|}{$\mathrm{K}$} \\
\hline & $\mathbf{M}$ & $\mathbf{F}$ & M & $\mathbf{F}$ & M & $\mathbf{F}$ & $\mathbf{M}$ & $\mathbf{F}$ \\
\hline I need to find the way to a shop that a friend has recommended. I would & 37 & 68 & 46 & 122 & 23 & 30 & 28 & 33 \\
\hline $\begin{array}{l}\text { A website has a video showing how to make a special graph or chart. There } \\
\text { is a person speaking, some lists and words describing what to do and some } \\
\text { diagrams. I would learn most from; }\end{array}$ & 40 & 85 & 39 & 51 & 17 & 42 & 38 & 75 \\
\hline I want to find out more about a tour that I am going on. I would & 37 & 55 & 44 & 99 & 23 & 31 & 30 & 68 \\
\hline When choosing a career or area of study, these are important for me: & 19 & 32 & 51 & 111 & 18 & 23 & 46 & 87 \\
\hline When I am learning I; & 16 & 40 & 30 & 48 & 47 & 53 & 41 & 112 \\
\hline $\begin{array}{l}\text { I want to save more money and to decide between a range of options, I } \\
\text { would }\end{array}$ & 13 & 37 & 44 & 86 & 33 & 35 & 44 & 95 \\
\hline I want to learn how to play a new board game or card game. I would: & 24 & 48 & 43 & 72 & 34 & 75 & 33 & 58 \\
\hline I have a problem with my heart. I would prefer that doctor: & 39 & 68 & 41 & 89 & 23 & 40 & 31 & 56 \\
\hline I want to learn to do something new on a computer. I would: & 13 & 32 & 40 & 79 & 37 & 44 & 44 & 98 \\
\hline When learning from the internet. I like: & 19 & 35 & 8 & 26 & 32 & 63 & 75 & 129 \\
\hline I want to learn about a new project. I would ask for: & 26 & 65 & 32 & 69 & 32 & 55 & 44 & 64 \\
\hline I want to learn how to take better photos. I would: & 22 & 32 & 53 & 81 & 21 & 56 & 38 & 84 \\
\hline I prefer a presenter or a teacher who uses: & 20 & 40 & 51 & 91 & 25 & 43 & 38 & 79 \\
\hline $\begin{array}{l}\text { I have finished a competition or test and I would like some feedback. I } \\
\text { would like to have feedback: }\end{array}$ & 12 & 26 & 50 & 73 & 46 & 74 & 26 & 80 \\
\hline $\begin{array}{l}\text { I want to find out about a house or an apartment. Before visiting it I would } \\
\text { want: }\end{array}$ & 25 & 64 & 57 & 97 & 28 & 46 & 24 & 46 \\
\hline $\begin{array}{l}\text { I want to assemble a wooden table that came in parts (kitset).I would learn } \\
\text { best from: }\end{array}$ & 27 & 50 & 43 & 60 & 23 & 69 & 41 & 74 \\
\hline Total score & 389 & 777 & 672 & 1254 & 462 & 779 & 621 & 1238 \\
\hline
\end{tabular}


Gender has a profound effect on learning style preferences. The results of the present study reported that both graduate and undergraduate female pharmacy students had relatively more preference for visual sensory learning modalities as compared to male students. The majority of the female graduate students were kinesthetic learners, whereas male graduate students were predominantly aural learners. This might be due to the fact that females are relatively more interested in improving their academic performance as compared to males. Similar findings were reported from a study conducted on medical students in Malaysia, which showed that the majority of the students preferred the auditory learning style (Muralidhara et al., 2013). Moreover, the present study findings revealed that both undergraduate and graduate pharmacy male and female students were using aural learning style as their preferred learning style. Similar findings were reported in a study where the aural mode of learning was the predominant style among medical students (Chaudhry, Ashar, \& Ahmad, 2020).

\section{Conclusion}

The result of the present study concluded aural as the most preferred learning style followed by kinesthetic among both undergraduate and graduate pharmacy students. Graduate female pharmacy students showed more preference towards kinesthetic learning style as compared to male graduate students who showed more preference towards aural learning modality. However, both undergraduate and graduate male and female students preferred aural learning styles. Identifying the learning style at the start of a pharmacy degree can help mentors to assess the appropriate field for them after graduation. It is also necessary to assess whether the style changes over time which could help to incorporate curriculum changes. Moreover, information regarding such styles would be helpful for stakeholders to devise effective strategies for teaching and introduce changes accordingly into the curriculum.

\section{Conflict of Interest}

The authors declare no conflict of interest.

\section{References}

Adams, M.E., Bell, L.A. E., \& Griffin, P.E. (2007). Teaching for diversity and social justice: Routledge/Taylor \& Francis Group

Ahil M.S., Sarojini R, \& R., P. (2016). A cross-sectional observational study on the attitude of medical students about the existing curricular patterns in medical education. International Journal of Science and Research, 5(8), 1481-1483
Ahmady, S., Khajeali, N., Sharifi, F., \& Mirmoghtadaei, Z. S. (2019). Factors related to academic failure in preclinical medical education: A systematic review. Journal of Advances in Medical Education \& Professionalism, 7(2), 74

Al-Saud, L. M. S. (2013). Learning Style Preferences of First-Year Dental Students at King Saud University in Riyadh, Saudi Arabia: Influence of Gender and GPA. Journal of dental education, 77(10), 1371-1378

Bhalli, M. A., Khan, I. A., \& Sattar, A. (2016). Learning style of medical students and its correlation with preferred teaching methodologies and academic achievement. Journal of Ayub Medical College Abbottabad, 27(4), 837-842

Breckler, J., Joun, D., \& Ngo, H. (2009). Learning styles of physiology students interested in the health professions. Advances in physiology education, 33(1), 30-36

Chaudhry, N.A., Ashar, A., \& Ahmad, S.A. (2020). Association of visual, aural, read/write, and kinesthetic (VARK) learning styles and academic performances of dental students. Pakistan Armed Forces Medical Journal, 70(Suppl-1), S58-63

Fooladi, M.M. (2008). Gender influence on nursing education and practice at Aga Khan university school of nursing in Karachi, Pakistan. Nurse Education in Practice, 8(4), 231-238

Khalil, M.M., Ahmed, M.G.A.D., \& Gawish, S.M. (2014). Towards better understanding of medical students learning styles of preclinical and clinical medical students. South East Asian Journal of Medical Education, 8, 20-28

Khan, T. (2011). Challenges to pharmacy and pharmacy practice in Pakistan. The Australasian medical journal, 4(4), 230

Khanal, L., Giri, J., Shah, S., Koirala, S., \& Rimal, J. (2019). Influence of learning-style preferences in academic performance in the subject of human anatomy: an institution-based study among preclinical medical students. Advances in medical education and practice, 10, 343

Muralidhara, D.V., Simbak, N., Nor, M.N.M., \& Nasir, M. (2013). Learning style preferences of preclinical medical students in a Malaysian university. South-East Asian Journal of Medical Education, 7(1), 23

Qureshi, S., \& Ullah, R. (2014). Learning Experiences of Higher Education Students: Approaches to Learning as Measures of Quality of Learning Outcomes. Bulletin of Education and Research, 36(1), 79-100

Radwan, N. (2014). An Adaptive Learning Management System Based on Learner's Learning Style. International Arab Journal of eTechnology, 3(4), 228-234

Rezigalla, A.A., \& Ahmed, O.Y. (2019). Learning style preferences among medical students in the College of Medicine, University of Bisha, Saudi Arabia (2018). Advances in medical education and practice, 10, 795

Robles, J., Cox, C. D., \& Seifert, C. F. (2012). The impact of preceptor and student learning styles on experiential performance measures. American journal of pharmaceutical education, 76(7)

Samarakoon, L., Fernando, T., Rodrigo, C., \& Rajapakse, S. (2013). Learning styles and approaches to learning among medical undergraduates and postgraduates. BMC medical education, 13(1), 1-6 